\title{
Introduction: The Material Worlds of Food in Early Modern Europe
}

\author{
Melissa Calaresu \\ Gonville and Caius College, Cambridge \\ mtc12@cam.ac.uk
}

\begin{abstract}
All of the articles in this special issue show the necessity of having to combine different kinds of sources - texts with images, images with objects, and objects with absences - to build an integrated history of the material worlds of food in the early modern period. They also reflect newer approaches to materiality which are sensitive to the relationship between matter and the senses and consider the haptic, visual, olfactory, and even aural aspects of cooking and eating alongside taste. In turn, the tastes of collectors and the fragility and absence of source material also need to be taken into consideration in order to write a meaningful cultural and social history of food. Despite the ephemeral nature of eating and cooking, this special issue shows that the sources studied by historians of material culture of the early modern period are remarkably rich, and their analysis fruitful.
\end{abstract}

\section{Keywords}

food - material culture - eating - dining - ceramics - early modern Europe

\section{Introduction}

While food is central to human existence, the material traces of cooking and eating in the past rarely survive. Surprisingly, food remains are listed in museum catalogues around the world, such as a carbonized fig dug up from a First Dynasty archaeological site in Egypt or some potato charms carried in 
trouser pockets to cure gout from early twentieth-century Winchester. ${ }^{1}$ These objects survive not to be eaten, but instead were treasured or preserved for a reason beyond mere sustenance, reminding us that food created identities and was believed to have protective, intercessory or curative powers, in life or after death.

In the Museum of Archaeology and Anthropology in Cambridge, three Kentish cakes commemorate the generosity of twins Elisa and Mary Chulkhurst from Biddenden who were supposed to have left a benefaction to the parish in the Middle Ages. From at least the end of the eighteenth century, cakes or biscuits were made in their image to be distributed to the poor on an annual basis (Figure 1). Collectors from the late nineteenth century believed the cakes to be material evidence of a continuous popular tradition, and these cakes were collected by The Folklore Society when they were made in $1923 .{ }^{2}$ The sisters' names and date of birth and the name of the village appear raised on the brittle surface of the cakes along with naïve representations of their faces and what look like eighteenth-century bodices. Broken at their edges and glued together again by later conservators, they are not only witnesses to the popular beliefs behind this tradition but also the molds from which they were made and the hands that pressed them. They are also witnesses to their collection. Along with the potato charms, the survival of these cakes is due to the interests and practices of late nineteenth- and early twentieth-century collectors and the expanding frameworks of archaeology and then anthropology as disciplines. While the Biddenden cakes might materialize early modern food practices or be an invented tradition, a whole range of other less fragile objects do survive from the period - most of them elite objects related to serving food which have been the subject of study by art historians and, increasingly, cultural and social historians.

The materiality and tangibility of these surviving objects contrast with the ephemerality of the act of eating and also the intangibility of the knowledge and practices around food and eating in the early modern period. In turn, material culture historians of food are required to consider and build stories from the absences as well as survivals in libraries, archives, and museum collections. This special issue presents novel approaches to understanding the history and culture of food-a rapidly expanding discipline - through objects, images, and texts from the early modern period. Food has become increasingly the

1 See, for example, "Fig, carbonised," Fitzwilliam Museum, E.48.190o, and "Charm-Two Potatoes," Museum of Archaeology and Anthropology, Cambridge, Z 45048 A-B. My thanks to Lissa Caldwell for her suggestion to look in the museum catalogues for organic food remains.

2 See the discussion of Biddenden cakes which date from the late nineteenth century and are now in the Pitt Rivers Museum, Oxford, accessed September 17, 2019, https://england.prm .ox.ac.uk/englishness-imaging-biddenden-maids.html. 


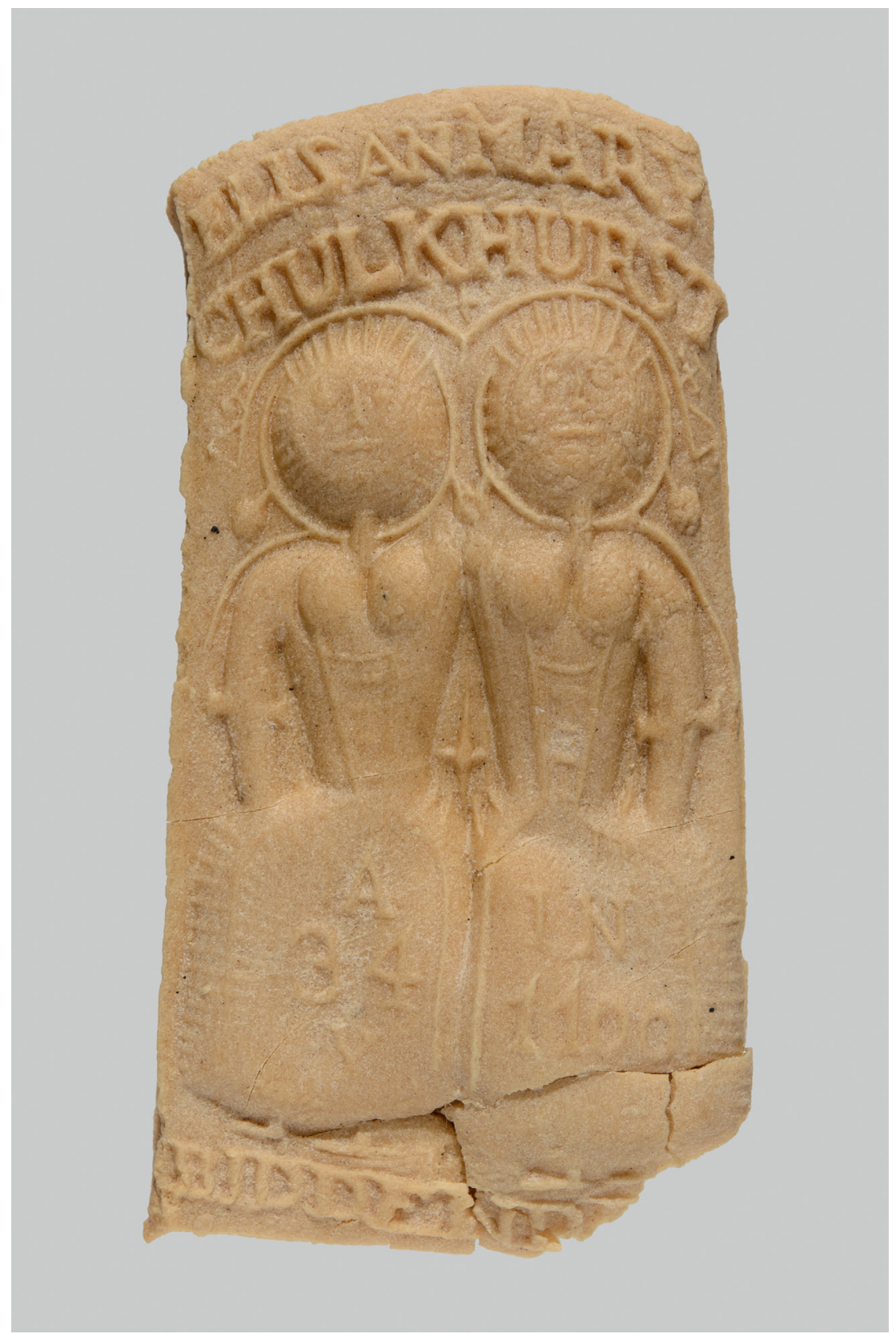

FIGURE 1 "A Biddenden cake bearing a raised design of 'two maids," Kent, England.

Deposited by the Folklore Society, 1923. D.1923.40. Museum of Archaeology and Anthropology, University of Cambridge.

THIS IMAGE IS COPYRIGHT. REPRODUCED BY PERMISSION OF UNIVERSITY of CAMBridge MUSEUM OF ARCHAEOlogy \& ANTHRopology (D1923.40). 
focus of historical research. ${ }^{3}$ For the early modern period, in particular, food has been at the center of a number of monographs, although its meanings have been primarily analyzed through texts rather than through objects. ${ }^{4}$ Historians of the decorative arts have certainly engaged with objects related to dining but, as one historian notes, the questions of how the objects were used and what food went in them have not been their primary concern until more recently. ${ }^{5} \mathrm{~A}$ notable exception is the work of Ivan Day who has successfully combined expert knowledge of cooking practices with attention to how food was displayed, through texts, objects, and experimentation. ${ }^{6}$ Another inspiration comes from the work of Sara Pennell whose attention to what she calls "mundane materiality" has been especially fruitful for early modern historians of the material culture of food, as she moves beyond texts and considers the materiality of the objects themselves. ${ }^{7}$ Even the field of food studies has had a recent "material turn," opening up new ways to approach the questions of embodiment and the agency of food. ${ }^{8}$ This special issue therefore proposes to draw and build on this recent work which is testimony to the richness of food as a theme through which to write early modern history.

3 See the journals Food and History from 2003 and, most recently, Global Food History from 2015. See also Bloomsbury's multi-volume series on the "Cultural History of Food" from antiquity to the modern age; in particular, for the early modern period, see the volumes edited by Ken Albala and Beat Kümin respectively, A Cultural History of Food in the Renaissance and A Cultural History of Food in the Early Modern Age (London, 2012).

4 See, for example, Rebecca Earle, The Body of the Conquistador: Food, Race, and the Colonial Experience in Spanish America, 1492-1700 (Cambridge, 2012); Emma Spary, Eating the Enlightenment: French Food and the Sciences, 1670-1760 (Chicago, 2012); and Christopher Kissane, Food, Religion and Communities in Early Modern Europe (London, 2018). It is worth noting that the 2013 Oxford Symposium was dedicated to the theme of food and material culture, the proceedings of which are cited in the footnote below.

5 Caroline C. Young, "The soup that went into the tureen: Connecting dots between Food and Material Culture," in Food and Material Culture: Proceedings of the Oxford Symposium on Food and Cookery 2013, ed. Mark McWilliams (Totnes, 2014), 35.

6 See, most recently, Day's contributions in Feast \& Fast: The art of food in Europe, 1500-180o, eds. Victoria Avery and Melissa Calaresu, Exhibition catalogue, Fitzwilliam Museum, Cambridge (London, 2019).

7 See, for example, Sara Pennell, "Mundane materiality, or should small things be forgotten?," in History and Material Culture, ed. Karen Harvey (London, 2009), 173-191; and, "For a crack and a flaw despis'd': Thinking about Ceramic Semi-Durability and the 'everyday' in Early Modern England," in Everyday Objects: Medieval and Early Modern Material Culture and its Meanings, eds. Tara Hamling and Catherine Richardson (Farnham, 2010), 27-40.

8 See Emma-Jayne Abbots' introduction to a special issue on "Food Stuffs: Materialities, Meanings, and Embodied Encounters," in Gastronomica: The Journal of Critical Food Studies 16, no. 3 (2016): 1-4, and, more recently, her monograph, The Agency of Eating: Mediation, Food, and the Body (London, 2017). 
Texts and images have traditionally been important sources for the history of food in the early modern period. The emergence of printed cookery books created new publics, even if recent research suggests that scholars rather than actual cooks might have been their readers, and that they are as much prescriptive as practical texts. In turn, the divide between printed cookery books and recipe manuscripts has been elided by recent research which recognizes the connections between these two forms of knowledge production, rather than being simply divided by gender and ideas of the domestic. ${ }^{9}$ Illustrated cookery books are particularly fruitful sources, as the work of Deborah Krohn on Bartolomeo Scappi's 1570 cookery book has shown, and her discussion here of Renaissance Italian and German carving manuals demonstrates not only the complexity of the relationship between text and image within the history of printing, but also the extent to which they can also be interrogated as sources for understanding practice. Thus, the illustrations of disembodied hands folding napkins (Figure 5 in Krohn) might help us animate the Renaissance table, even if the realities of domestic service-for example, the need to wipe greasy hands on a linen napkin after handling a large piece of meat-are obscured. Current museological practice, in fact, emphasizes the labor behind the serving of meals in historic houses and museum displays. ${ }^{10}$ However, the similarity of the carving manual illustrations to early modern representations of the instruments of the Passion in the early modern period, as Krohn suggests, takes us back to more mainstream forms of representation.

The difficulties and potential of images as sources for an integrated history of food are clear from an album of drawings made for the Gonzaga family at Mantua in the 1520s. While it does not represent actual objects in situ, as in the case of the Scappi illustrations, the album shows designs for elaborate silver and gilt table ware for "Popes, Cardinals, and other great lords" to be ordered for display on their sideboard (credenza) or use at their table. ${ }^{11} \mathrm{~A}$ spectacular

9 Deborah L. Krohn, Food and Knowledge in Renaissance Italy: Bartolomeo Scappi's Paper Kitchens (London, 2015), 113-162; Sara Pennell and Michelle DiMeo, eds., Reading and Writing Recipe Books, 1550-180o (Manchester, 2013); and Elaine Leong, Recipes and Everyday Knowledge: Medicine, Science, and the Household in Early Modern England (Chicago, 2019), esp. 147-172.

10 There was a projection of disembodied hands over a table in a recent reconstruction of the Royal Kitchens at Kew Palace; on kitchen displays in period rooms and historic houses, see Deborah L. Krohn, "Picturing the Kitchen: Renaissance Treatise and Period Room," West 86th: AJournal of Decorative Arts, Design History, and Material Culture 16, no. 1 (2008-2009): 20-34, and, more recently, Sara Pennell, "The Kitchen Displayed," in The Birth of the English Kitchen, 1600-1850 (London, 2017), 159-171.

11 The inscription for the album reads: "Libro de dissegni per far vasella di argento et oro per servitio della credenza e tavola $\mathrm{p}[\mathrm{er}]$ un gran Principe fatte tutte al modo antico et 
variety of ewers, basins, candlesticks, salt cellars, and goblets is richly illustrated and the reference to the credenza suggests that these beautiful and valuable objects might have been solely for display. The complexity, impracticality, and singularity of some of the designs and the prospect of their use-for instance, for a pepper pot-strengthens this argument (Figure 2)..$^{12}$ Yet, there are also clues to lived experience of Renaissance dining practices in the album. The largest number of designs in the albums are dedicated to ewers and basin, reminding us of the practice and importance of washing hands before a meal to be eaten without forks across Europe, including the Ottoman world. ${ }^{13}$ The distinction between different sized salt-cellars-medium ones "for the long Table when the Prince holds a banquet" and smaller ones "for when the prince eats alone"-suggests different dining needs at different times in a courtly context. ${ }^{14}$ The distinction in the inscriptions between kinds of glasses-for drinking water and drinking wine-suggests material differences when these different beverages were served, even if one must consider further the (im) practicalities of drinking out of the "Two-handled cup for drinking water" with one's mouth (Figure 3). ${ }^{15}$ The imaginative qualities of the designs, however, must not obscure their contribution to understanding the material cultures of food in the early modern period. The candlestick designs remind us of the need to illuminate dining spaces, even during the day, and that the reflections of the candle's flames would have shone and flickered on the silver and gilt tableware-doubling the conspicuousness of this display of consumption, by which the value of the candles could also be detected by the smell of the kind of wax used. ${ }^{16}$ The static images of pails with swing handles for water remind us not only of the need to bring water to the table, but also the movement and

come hoggi si usano in Roma per la Tavola del Papa et Cardinali et altri gran signori, li quali dissegni sonno poste per ordine come qui sotto sonno nominate; nel modo come in Roma se aparecchiano le credenze et tavole su nominate diligentissimi dissegnati, sonno pezzi ${ }^{\circ}$. cento," Fitzwilliam Museum, PD.6-1948, f. 1. For images from the entire album, see http://data.fitzmuseum.cam.ac.uk/id/object/9514.

12 This corresponds to one of "Due peparole $\mathrm{p}$ [er] tenere il pepe sopra alla tavola del Principe," cited in the inscription PD.6-1948, ff. 22-23.

13 The inscription reads: "Bochali per dar aqua alle mani di varie sorte / Bochali per dar aqua alle mani con li suoi Bacilli."

14 The inscription reads: "Salliere mezzane per la Tavola longa, quando un Principe fa banchetto./ Salliere picole quando il principe magna solo."

15 The inscription reads: "Tazze Varie per ber vino. / Tazze alte; et bichieri per ber aqua. [...] Due vasi bassi con manichi per ber aqua."

16 On the materiality of illumination at a Renaissance court, see Timothy McCall, "Brilliant bodies: Material Culture and the Adornment of Men in North Italy's Quattrocento Courts," I Tatti Studies in the Italian Renaissance, 16, no. 1-2 (2013): 445-490; on the social value of an illuminated salon in eighteenth-century Paris, see Mimi Hellman, "Enchanted 


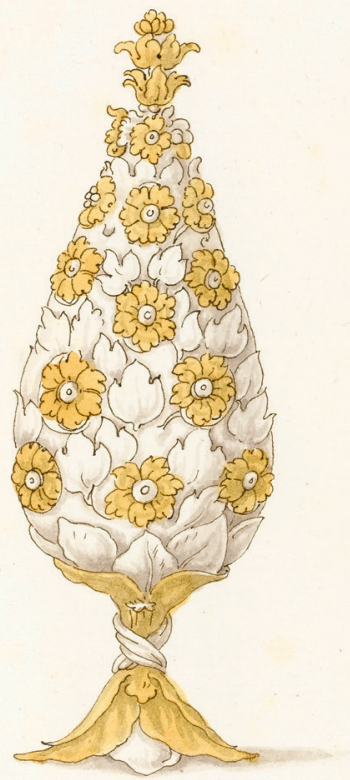

FIGURE 2 "Pepper pot," by unknown artist after Giulio Romano (c. 1499-1546), "Libro de dissegni per far vasella di argento et oro per servitio della credenza e tavola [...]," sketchbook of designs for silver and gold tableware, Northern Italy c. 1569-1582. Pen and brown ink, yellow and grey-brown wash on paper, in album of 100 designs, bound in vellum, $40.6 \times 28 \mathrm{~cm}$. PD.6-1948, f. 22, Fitzwilliam Museum, University of Cambridge. PHOTO (C) THE FITZWILLIAM MUSEUM, CAMBRIDGE. 


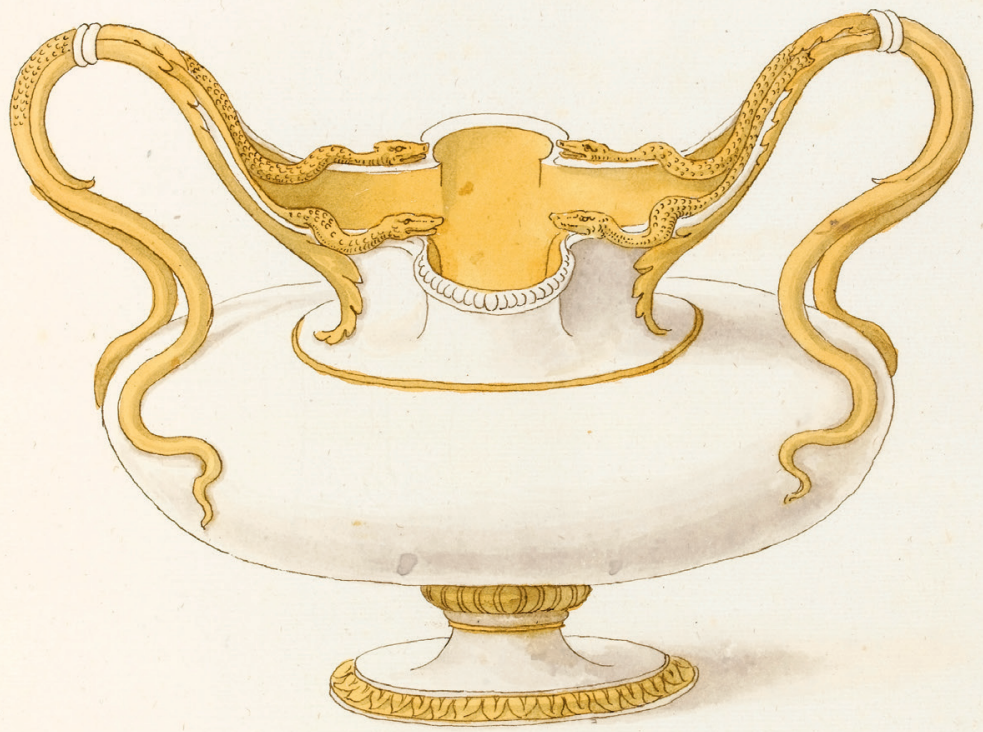

FIGURE 3 "Two-handled cup for drinking water," from “Libro de dissegni," PD.6-1948, f. 6o, Fitzwilliam Museum, Cambridge. PHOTO (C) THE FITZWILLIAM MUSEUM, CAMBRIDGE. 
sounds of the handles swinging back and forth and the water swishing in them, as diners ate and demanded service of their servants (Figure 4). ${ }^{17}$

As Helen Pfeifer's article reminds us, the social complexity at the early modern table is not always accompanied by such material abundance. Her analysis of an Ottoman text on table manners demonstrates this complexity without the presence of the variety and quantity of tableware used at the Gonzaga court. Her interpretation also demonstrates clearly the agency of the space and spaces between bodies and objects, while eating and being served at the Ottoman table, which was as powerful and significant as the agency of objects themselves. It questions directly the extent to which fixed tables as well as the "emergence" of individual forks, plates, and specialized serving ware in the early modern period continue to be harnessed to the discourse of civilization and modernity, inspired by the work of Norbert Elias, in current histories of material culture and food.

The quantity as well as quality of surviving material has determined the historical study of food practices in early modern Europe. And, yet, fasting as well as feasting were central to the social and cultural life of this period. That there is less material evidence for this practice is a methodological problem recognized by prehistoric archaeologists, whose sources are dominated by evidence related to eating rather than not eating. ${ }^{18}$ Some objects related to abstention from eating certain foods in the early modern period do survive, such as this earthenware pipkin dated 1650 , with a broken handle and small lip for pouring and inscribed with the words, "Fast and pray 1650 " (Figure 5). Burnished on the bottom, one can only imagine it being used to heat up one of the vegetable pottages suggested by Thomas Tryon during Advent or Lent, the cleansing qualities of which must have been both spiritual and physical. ${ }^{19}$ We know little about the food practices around fasting in England, and this rare survival would need

Night: Decoration, Sociability, and Visuality after Dark," in Paris: Life and Luxury in the 18th century, ed. Charissa Bremer-David (Los Angeles, 2011), 91-114.

17 On sound in the Renaissance home, see Flora Dennis, "Sound and Domestic Space in Fifteenth- and Sixteenth-Century Italy," West 86th: A Journal of Decorative Arts, Design History, and Material Culture 16, no. 1 (2008): 7-19; and, "Resurrecting Forgotten Sound: Fans and handbells in early modern Italy," in Everyday Objects, eds. Hamling and Richardson, 191-210.

18 Michael Dietler, "Feasting and fasting," in The Oxford Handbook of the Archaeology and the Ritual of Feasting, ed. Tim Insoll (Oxford, 2011), 187-188.

19 Tryon writes of a herb pottage as cleansing, Thomas Tryon, Wisdom's dictates, or, Aphorisms \& rules, physical, moral, and divine, for preserving the health of the body, and the peace of the mind, fit to be regarded and practised by all that would enjoy the blessings of the present and future world ... (London, 1691), 149. The accounts for the Willoughby household in Middleton, Warwickshire, referred to the "clensynge dayse afore crystynmes" in Advent 


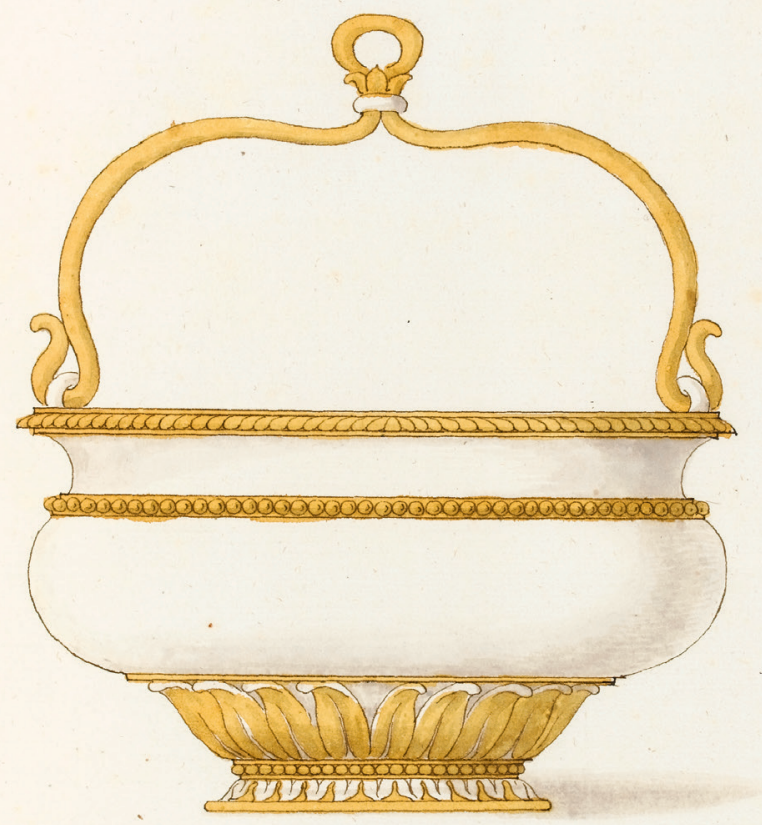

FIGURE 4 "Pail with swing handle," from Guilio Romano, "Libro de dissegni," Fitzwilliam Museum, in PD.6-1948, f. 61, Fitzwilliam Museum, University of Cambridge. PHOTO (C) THE FITZWILLIAM MUSEUM, CAMBRIDGE. 


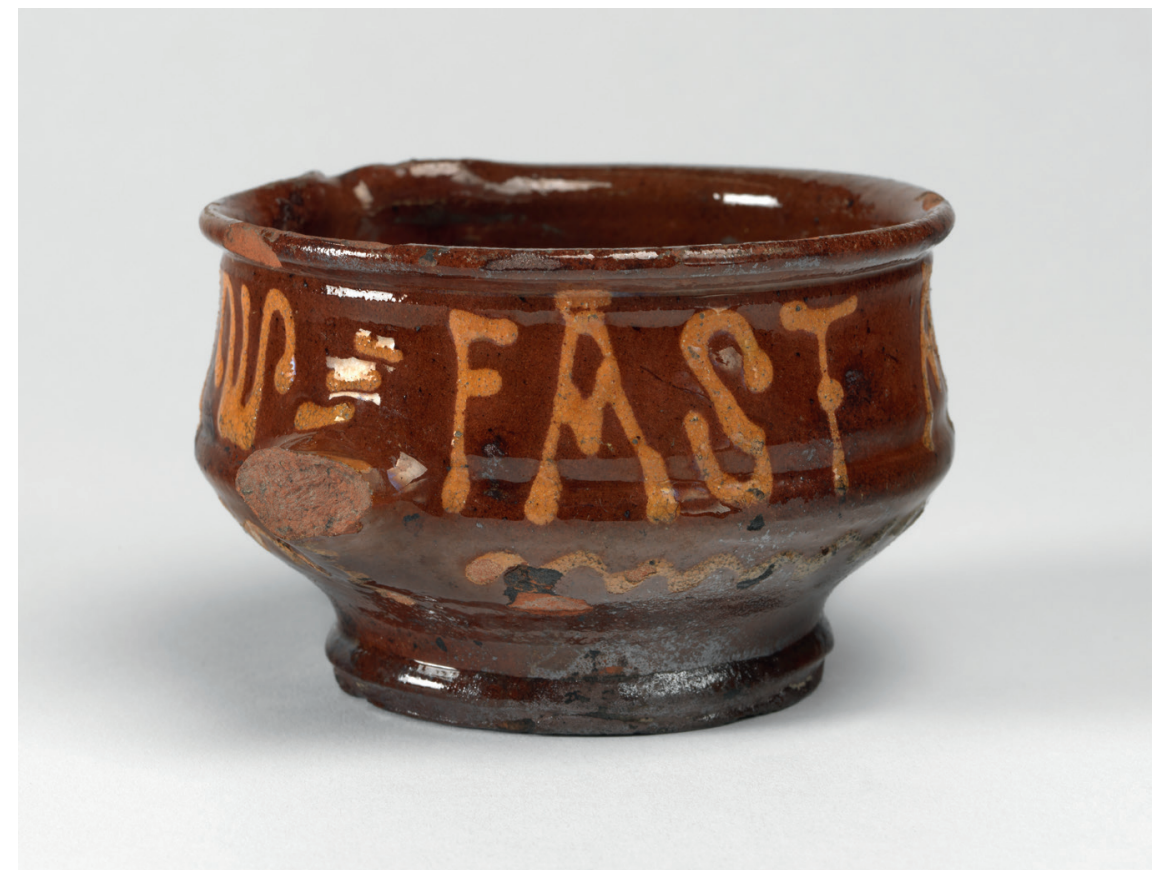

FIGURE 5 Slipware pipkin. Unidentified Harlow pottery, Essex. Red earthenware, thrown, with dark cream slip-trailed decoration under yellowish lead glaze, which does not cover the base inside, height, whole, $6.8 \mathrm{~cm}$, diameter, whole, $11.3 \mathrm{~cm}$, dated 1650. GL.C.35-1928, Fitzwilliam Museum, University of Cambridge. PHOTO (C) THE FITZWILLIAM MUSEUM, CAMBRIDGE.

further study alongside prescriptive texts and other "moralizing" objects, such as those studied by Alexandra Walsham in her article in this issue. ${ }^{20}$

Historians of cooking and eating, the most ephemeral of human activities, therefore require strategies to contend with a lack of material evidence and are forced to develop their analyses with different kinds of sources and approaches. While the organic food remains in current museum collections could be the subject of material analysis to determine authenticity, there is no doubt that the collector believed that the Biddenden cakes materialized earlier culinary and cultural traditions. Similarly, historians of ordinary eating practices

1521, Mark Dawson, Plenti and Grase: Food and Drink in a Sixteenth-Century Household (Totnes, 2009), 220.

20 On this fasting ceramic, see the entry in Feast \& Fast eds. Avery and Calaresu, 206-207; on "Protestant pots," see also Andrew Morrall, "Protestant Pots: Morality and Social Ritual in the Early Modern Home," Journal of Design History 15 (2002): 263-273. 
in the early modern period sometimes presume continuities in cooking and dining practices through to the later periods to make up for this lack of material evidence. For example, the description of simple cooking technologies by Dorothy Hartley in her book, Food in England, first published in 1954, but dating back to her own eating and cooking experiences at the turn of the twentieth century, imply continuities with the medieval and early modern period. ${ }^{21}$ This approach can also be combined with an analysis of visual sources. For instance, there is significant visual evidence of elite dining practices in the Ottoman Empire, but much less rich material evidence. Ottoman historians sometimes rely on later objects from the nineteenth century to construct their histories, for example, in the case of the dining napkin discussed by Pfeifer (Figure 5 in Pfeifer).

Reconstructing the specific assemblages of these items on the table has proven a challenge too. As Krohn's article demonstrates, folded napkins were central to elite table display, as the practice of folding illustrated in Renaissance carving manuals confirms, but texts have their limits. Napkin displays, in any case, cannot be studied in isolation. They would have been part of a structured display of objects made of glass, majolica, silver, and later porcelain, many of which have survived, as well as the folded napkins, sugar sculptures, and the tableside performance of serving guests, most of which have not survived. The historical reconstructions by Joan Sallas and Ivan Day have closed this gap between extant and lost objects by animating early modern table displays and practices for contemporary audiences in innovative ways. ${ }^{22}$ However, the ephemerality of these practices continues to present methodological difficulties. Reflection on the nature of different materials as well as further experimentation in remaking or reconstruction allow us to consider further the agency of and relationship between objects, bodies, and spaces. The tugging of a communal napkin between Ottoman diners suggests how objects served to articulate these. ${ }^{23}$

21 See, for example, her illustrations of a "Bargee's Pail" and a medieval cauldron as similar forms of "slow-cooking," in Dorothy Hartley, Food in England (first edition 1954, London, 1999), 37.

22 For Sallas' contribution to the Palazzo Pitti exhibition which included both sugar sculpture and napkin displays for the reconstruction of the wedding feast of Maria de' Medici in October 1600, see Giovanna Giusti and Riccardo Spinelli, Dolci trionfi e finissime piegature. Sculture in zucchero e tovaglioli per le nozze fiorentine di Maria de' Medici (Palazzo Pitti, Florence, March-June 2015). See also Ivan Day, Royal sugar sculpture (Bowes Museum, 2002), and more recently, June di Schino, "The Significance and Symbolism of Sugar Sculpture at Italian Court Banquets," in Food and Material Culture, ed. McWilliams, 68-81.

23 Ulinka Rublack, "Matter in the Material Renaissance," Past \& Present 219, no. 1 (May 2013): 41-85. 
In turn, recent research recognizes the role of the senses in the material reconstruction of early modern practices - the visual, the olfactory, and the haptic are all part of the display and eating of food. ${ }^{24}$ The smell of cooked dishes would have been less powerful than the bodily odors of early modern diners, which were counteracted by herb-filled pomanders on their bodies, perfume burners on the floor and the scented gloves by their side, and all this would have combined with the smell of tallow or beeswax candles to light the table. ${ }^{25}$ In turn, the fleeting aural experience of the clatter of knives hitting the majolica or pewter dishes, together with the delicate nature of textiles and sugar sculptures — often reused, recycled, and eventually thrown away — means that the ceramic plates and silver tableware are all that survive of these ephemeral eating experiences in museum collections today.

The field of material culture studies has been shaped by the interests and motives of specific collectors. For instance, the extensive ceramic collection of Dr. James Glaisher in the Fitzwilliam Museum in Cambridge provides us with important evidence for the contextualization of more ordinary eating practices. Yet, Glaisher's intentions were not necessarily to materialize a history of early modern food. His interest in the forms of objects was connected to the chronological mapping of ceramics which dominated collectors' handbooks in the late nineteenth and early twentieth century. Posset pots, which were used to make a warm custard drink, mixed with alcohol, were particularly popular with collectors like Glaisher because of their unusual shape. Posset pots came in a variety of forms and decorations, such as this one with a dome-shaped cover and decoration of squares and diamonds (Figure 6), and Glaisher's descriptions of them are full of comments about colored glazes, figures, and ceramic handles and lids in his manuscript catalogue. ${ }^{26}$ Their "sucking spouts"

24 For instance, on the role of the smell of amber rosaries warmed up by praying hands, see Irene Galandra-Cooper and Mary Laven, "The Material Culture of Piety in the Italian Renaissance: Retouching the Rosary," in The Routledge Handbook of Material Culture in Early Modern Europe, eds. Catherine Richardson, Tara Hamling, and David Gaimster (Abingdon, 2017), 338-353.

25 On perfumed interiors, see Sandra Cavallo and Tessa Storey, Healthy Living in Late Renaissance Italy (Oxford, 2013), 101-103. On the social distinction of smells using different kinds of wax candles, see Hellman, "Enchanted Night," 96-99.

26 He writes: "this one appealed to me, partly because of the dome shaped cover and partly because of the decoration - not the flower decoration in which there is nothing unusual, but the 'diamonds' and the squares and square panels - as a posset pot in spite of the absence of a date and any very special feature I think it is an attractive and interesting one" (Glaisher MS Catalogue, vol. 19, no. 3873, Fitzwilliam Museum, Cambridge). 


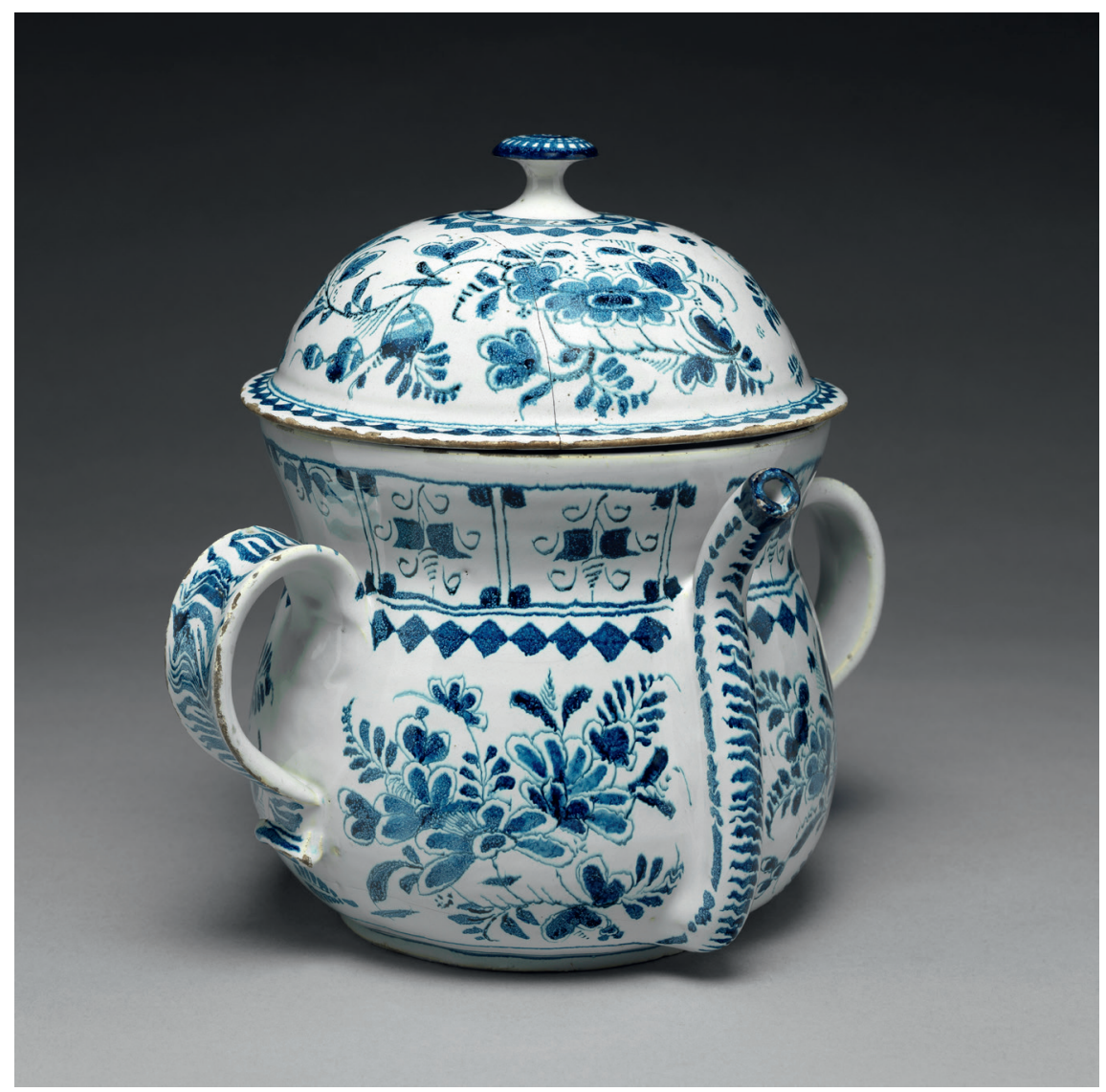

FIGURE 6 Posset pot and cover. Unidentified pottery, possibly London or Bristol, c. 1720-1730. Buff earthenware, thrown, with applied spout and handles with rolled terminals, covered with bluish-white tin-glaze and painted in blue. Height, whole, $23.8 \mathrm{~cm}$. C.136o \& A-1928, Fitzwilliam Museum, University of Cambridge. PHOTO (C) THE FITZWILLIAM MUSEUM, CAMBRIDGE.

were of particular interest to Glaisher and his contemporaries. ${ }^{27}$ These spouts, unlike those of a teapot, clung to the body of the pot, and were designed to enable the user to suck the alcoholic liquid at the bottom of the pot while the frothy foam floated above. Glaisher's understanding of the function of these spouts is significant, showing an awareness of their materiality. Glaisher was also an avid collector of ceramics that referenced fertility, including this

27 See, for example, his descriptions of sucking spouts for posset pots, tygs, and puzzle jugs, in Glaisher MS Catalogue, vol. 1, no. 26; vol. 6, no. 2873; vol. 17, no. 3637 and 3639; vol. 32, no. 4812 . 
sauceboat, analyzed by Walsham, in which a reclining nude would have been revealed as the sauce poured out (Figure $8 \mathrm{in}$ Walsham). Yet, in his manuscript catalogue, he focuses on form and decoration and does not refer to their possible function or meaning in relation to eating or serving food. ${ }^{28} \mathrm{In}$ fact, most of Glaisher's early modern ceramics survived because they had not been used on a daily basis; they had been kept safely above the busyness of the kitchen and treasured as wedding or christening gifts by the original owners and their descendants. ${ }^{29}$ Even if Glaisher did not intentionally collect for future food historians, Walsham's original analysis shows that these ceramics offer ample evidence for the contextualization of eating practices. She reveals the tensions between broader moral messages transmitted by these objects and the specific forms associated with the serving and eating of food, suggesting the existence of contradictions in the various early modern discourses about eating, the body, and Godliness, contradictions which go well beyond Glaisher's interests as a collector of unusual earthenware.

Many of the contributions in this issue largely focus on an exploration of food history, which is committed to histories of sitting down and eating at a table, an approach which is determined by the survival of sources such as books of table etiquette and tableware. ${ }^{30}$ Recent research, however, has gone outside of the house and focused on the role of production and provisioning of food. ${ }^{31}$ As Melissa Calaresu's article shows, the unusually detailed account book of Thomas Jones' purchases in Naples reveals the complex interconnectedness of foodways from the hinterland to the city, and from the city to the urban kitchen. As for most kitchens of this period, no material object survives from Jones' Neapolitan kitchen. Yet, his account book allows us to build a story of the workings of his household and link it to questions of storage and seasonality as well as to sources such as recipe books and tableware which are the mainstays of food history. In this way, a material culture approach to the history of food links the outside with the inside and can make a contribution to urban history.

28 C.1398-1928, Fitzwilliam Museum, Cambridge: "This dish was a favourite marriage present and I think all were intended for that purpose" (Glaisher MS Catalogue, vol. 28, no. 46o6).

29 Melissa Calaresu, "Everyday' Objects and the Glaisher Collection," in Treasured Possessions from the Renaissance to the Enlightenment, eds. Victoria Avery, Melissa Calaresu, and Mary Laven (London, 2015), 177-183.

30 Sara Pennell, "Getting Down from the Table: Early Modern Foodways and Material Culture," in The Routledge Handbook of Material Culture in Early Modern Europe, eds. Richardson, Hamling, and Gaimster, 185-195.

31 See "Introduction," in Food Hawkers: Selling Food in the Streets from Antiquity to the Present Day, ed. Melissa Calaresu and Danielle van den Heuvel (Abingdon, 2016), 1-18. 
All of the articles in this special issue show the necessity of having to combine different kinds of sources - texts with images, images with objects, and objects with absences - to build an integrated history of the material worlds of food in the early modern period. They also reflect newer approaches to materiality which are sensitive to the relationship between matter and the senses and consider the haptic, visual, olfactory, and even aural aspects of cooking and eating alongside taste. In turn, the tastes of collectors and the fragility and absence of source material also need to be taken into consideration in order to write a meaningful cultural and social history of food. Despite the ephemeral nature of eating and cooking, this special issue shows that the sources studied by historians of material culture of the early modern period are remarkably rich, and their analysis fruitful.

\section{Acknowledgements}

My thanks to the contributors to this issue for their comments on the introduction as well as their enthusiasm and patience in the production of this special issue. 